\title{
Model Soviet City of the Brezhnev Era: The Image of Kharkiv in Selected Propaganda Texts
}

\author{
Modelowe radzieckie miasto epoki Leonida Breżniewa: obraz Charkowa \\ w wybranych tekstach propagandy
}

\section{- Abstrakt •}

Celem artykułu jest przedstawienie propagandowego wizerunku Charkowa z okresu rządów Leonida Breżniewa w materiałach adresowanych do zagranicznego odbiorcy. Wyróżniono trzy kluczowe wątki powtarzające się w narracjach o Charkowie: relatywną „młodość” miasta, jego industrialne oblicze oraz funkcjonowanie silnego ośrodka akademickiego. Krytyczna analiza dyskursu propagandowego opiera się na założeniu, że język ów był nośnikiem ideologii, nie relacjonował rzeczywistości, ale jej ideologiczną wizję. Wyłaniający się z tekstu obraz Charkowa to wizja miasta, które spełniało modelowy, radziecki standard: nie był to komunistyczny ideał, do którego zbliżała się Moskwa, ani egzotyka Kaukazu lub Azji Centralnej, ale wzorcowa radziecka typowość. Była to duża, nowoczesna przemysłowa metropolia, poprawna ideologicznie, egzemplifikująca rdzeniową, słowiańską europejską część Związku Radzieckiego, a jej promocja była $\mathrm{w}$ istocie promocją całego radzieckiego systemu.

Słowa kluczowe: Charków; miasto socjalistyczne; miasto radzieckie; epoka Breżniewa; propaganda radziecka; rozwinięty socjalizm

\section{- Abstract •}

The aim of the paper is to present the image of Kharkiv in propaganda materials from the period of Leonid Brezhnev's rule addressed to foreign recipients. Three key threads repeated in narratives about Kharkiv were distinguished by the author: the relative "youth" of the city, its industrial character and the functioning of a strong academic center. The critical analysis of the propaganda discourse is based on the assumption that the language used was the carrier of ideology, i.e. it did not report reality, but its ideological vision. The image of Kharkiv emerging from the analysis is a vision of a city fulfilling the model Soviet standard: neither a communist ideal that Moscow was nearing, nor one with the exotic flair of the Caucasus or Central Asia. It was a Soviet model typicality: a large, modern industrial metropolis, ideologically correct, exemplifying the core, Slavic-European part of the USSR. Thus its promotion was in fact the promotion of the Soviet system as a whole.

Keywords: Kharkiv; socialist city; soviet city; Brezhnev era; soviet propaganda; developed socialism 


\section{Introduction}

Kharkiv, since its founding in the second half of the 17th century at the southern edge of the Russian Tsardom, has developed dynamically as a commercial, industrial, political, administrative, cultural, and scientific centre. It also boasts a university with now more than bicentennial tradition. As the deliberate settlement policy implemented by the Tsar attracted colonists of both Ukrainian and Russian ethnos, these ethnicities permanently shaped the city demographics. With the onset of the nationalist era, Kharkiv, the hitherto bulwark of Russian expansion to the south, became the arena of a symbolic competition between the Russian and Ukrainian national discourses. After the formation of the USSR, this rivalry was - to a varying extent - "toned down" by internationalist ideology, while Kharkiv itself was honoured with the status of capital city of a new Soviet republic. Strengthening of the Soviet rule, pacification of the previously politically uncertain Kiev, and transition to an ethnic policy based on trivialized traditions of national cultures (Martin, 2013, p 579; Slezkine, 1994, p. 447-449) led in 1934 to the decision to move the capital of the Ukrainian SSR to Kiev. Though provincialized in the political sense, Kharkiv nonetheless never lost its metropolitan nature; it transformed from a borderland city into an integral part of the unified Soviet cultural space (Kravchenko, 2011, p. 72; Kaganskii, 2004).

In this paper I will focus on the propaganda image of Kharkiv addressed to foreign recipients during Leonid Brezhnev's rule (1964-1982). Writing at the time required internalizing the spirit of the so-called developed socialism era and meant advocating the international superpower status of the USSR and the consumer prosperity "achieved" there. Indeed, Brezhnev's period of rule was the time of the highest living standards for the masses, in purely material terms. As a result, the attitude of the Soviet everyman evolved towards that of an informed consumer who wants to fulfil his needs without ideological supervision (Chernyshova, 2015). Glorification of state institutions providing comfortable living conditions to their citizens in the here and now was thus the main theme of the Brezhnev-era propaganda. At the same time, the new Soviet consumer increasingly ignored the propaganda messages as such and distanced himself from the Party's authority (von Bremzen, 2016, p. 178). Persistent discrepancy between the supply and demand of goods and inequality in access to them were just as characteristic of the "developed socialism" as was the perceptible improvement in living conditions compared to both earlier and later stages of the Soviet rule (Kul'chyc'kii, 2013, p. 266-269). Well aware of it, the Party used external propaganda to shape the desired image of the USSR not only abroad: publication of tourist guide-books 
and photo albums with translations (or at least summaries) in western languages (mainly English) also served as a means of Party self-promotion on the domestic market. These efforts, I believe, were meant to influence local Soviet recipients and persuade them that their state was objectively attractive to foreigners. Such use of the significant social authority of the "Abroad" was an attempt to counteract the erosion of the mental relationship between the Party and the masses.

There were at least three discernible components in the externally promoted image of Kharkiv. First, the relative "youthfulness" of the city and the role it played in institutionalizing the Soviet power in Ukraine, which enabled the seamless inclusion of Kharkiv's pre-revolutionary past into the Soviet historical discourse. Second, its industrial character, given to the city by its numerous industrial plants, most prominently the Kharkiv Tractor Plant. It was presented as a perfect combination of bleeding-edge technological solutions in production and highest living standards. The modern nature of the metropolis was underlined in many domains, such as housing, public transport, as well as commercial and cultural portfolio. Third, Kharkiv was advertised as a strong academic centre educating youth not only from the entire USSR but also from abroad. It was supposed to show the Soviet Union as open to the world and exemplify the practical implementation of the internationalist idea. I posit that emphasis on these three traits in descriptions of a city located in the European part of the USSR and inhabited mostly by a Slavic population was intended to turn the city itself into a showpiece of sorts, advertising the whole Soviet economic and political system.

In this way Kharkiv became a model Soviet city: neither ideal, nor average, but one whose image reflected the main components of the desired vision of the USSR as a whole: a leading power among the socialist and progressive countries, a strong industrial economy entering a new phase of scientific and technical progress, a frontrunner in space exploration, a state that provides its citizens with a stable present and a happy future.

\section{Research Data and Methodology}

The source material for the present paper can be divided into a number of categories. The first category comprises soviet-era tourist guide-books to Kharkiv. The following guide-books published by the "Prapor" publishing house in Kharkiv were used in the analysis: Khar'kov: Putevoditel' (Kharkov: Guide-book), in Russian and English, prepared for publication by Nikolai D'iachenko, Mikhail Umanskii and Vitalii Oleinik printed in 1967 (its Ukrainian-English original had been published 
three years earlier); Znakom'tes': Khar'kov: Putevoditel' (Get Familiar with Kharkov: Guide; Faites la connaissance de Kharkov: Guide), by (Galina Andreeva and Vitalii Oleinik) from 1982; a Russian-language guide book in essayistic form, published two years later, with English and German summaries - Vstrechi s Khark'ovom (Meetings with Kharkov; Begegnungen mit Charkow), written by (Iurii Gerasimenko), and Turistu o Kharkove: Putevoditel' (Kharkov: A Tourist's Guidebook) by Igor' Orlenko from 1986. Though the last two were published after Brezhnev's death, they show no signs of perestroika in their style and are fully representative for the "developed socialism" period. Two albums with photographs depicting Kharkiv and the Kharkiv Oblast can also be included in this category: Kharkivshchyna: Fotoal'bom (Kharkiv Region: Photoalbum), a collaborative work with Ukrainian and Russian text versions, published in Kiev by "Mystetstvo" in 1981 as well as Kharkiv (Khar'kov; Kharkov), edited by (V. Teslenko), which included a short text in Ukrainian, Russian, English, French, German, and Spanish, published in Moscow under the imprint of "Progress" (no publication date given). A book on the history of the city, Ulitsy i ploshchadi Kharkova. Iz historii goroda (Streets and Plazas of Kharkiv), by Nikolai D'iachenko (Prapor, 1965) belongs also to this category.

The second grouping is composed of press materials promoting Kharkiv published in the weekly magazine Kraj Rad (The Soviets' State) intended for Polish-speaking readers. The Soviets' State was a Soviet illustrated magazine published by the Warsaw branch of the Soviet Novosti Press Agency. Its editorial board was comprised of both Soviet and Polish editors. The weekly magazine was strictly propagandist in nature, and some of the content it published were unlabelled reprints from the conservative Soviet magazine Ogonek (Flame). Being a classical component of Soviet soft power, the Soviets' State had numerous counterparts both in people's democracy states and in the West. The research query for the purposes of this paper covered the whole period of the rule of Leonid Brezhnev (1964-1982).

The third category consists of press materials from the Poznań daily newspaper Gazeta Poznańska (The Poznań Gazette). Poznań and Kharkiv remain sister cities until today. Even though the partnership agreement was not formally signed until 1998, regular contacts at both the Party and local government level date back to the late 1950s. The Poznan Gazette kept the public informed about the members of Soviet delegations visiting Poznań, programs of their visits, and about Kharkiv itself. It also published reprints from the Krasnoe znamiia (Red Banner) thanks to its collaboration with this Kharkiv newspaper.

Finally, the fourth category used were archival documents collected in the Poznań Branch of the State Archives, originating from the Regional Committee of the Polish United Workers' Party (PZPR) and several District Committees of 
PZPR in Greater Poland Voivodeship. Though these materials provided some information on bilateral cooperation between Kharkiv and Poznań, they played the least significant role in the analysis performed due to their superficial and rather clerical nature. As it turned out, they did not form a coherent and chronologically ordered whole documenting the "for export" image of Kharkiv that I expected to find at the preliminary stage of my research.

Analysis of the studied material was based on several underlying assumptions. One, that the language of the Soviet propaganda - newspeak or, in the words of Françoise Thom, the wooden language - served just one function: being the carrier of ideology (Thom, 1990, p. 8). In the "developed socialism" era, the Marxist-Leninist ideology had already been supplemented with interpretations by Stalin, Khrushchev, and Brezhnev, thus reaching a certain maturity. It allowed, according to Thom, to stabilise the wooden language into "false serenity" (Thom, 1990, p. 136). The predominant trends in the Brezhnev era newspeak were ostentatious patience, soothing objectification of facts - as if from the perspective of a mature teacher - and solemn dignity (Thom, 1990, p. 136-137). The purpose of information delivered to recipients through this language was not to teach about the world, but to describe it in appropriate terms and align it with the guidelines of political doctrine (Głowiński, 1991, p. 38-40). After the 20th Congress of the Communist Party of the USSR, where Krushchev announced the transition to communism within the next twenty years, the doctrine necessitated shortening the distance between the present and the utopian vision of the bright future. What is also crucial is that the Soviet propaganda of that period exemplifies the rational type of propaganda (Ellul, 2006, p. 41-42), i.e., propaganda based not on emotional engagement of the recipients, but rather on facts, statistics, and economic ideas. "Soviet propaganda, especially since 1950, has been based on the undeniable scientific progress and economic development of the Soviet Union; but it is still propaganda, for it uses these facts to demonstrate, rationally, the superiority of its system and demand everybody's support" (Ellul, 2006, p. 42). That the statistics used were of dubious reliability and practically unverifiable was an entirely separate issue of no consequence to the operation of the propaganda mechanism. I would like to supplement Ellul's statement on rationality of Soviet propaganda though: it did not entirely abandon extra-rational themes. Appeals to memory, experience, and emotions lay at the foundation of Brezhnev's narrative about World War II, which gave rise to cult of veterans, commemoration of both victims and combatants in the public space, and spectacular celebrations of Victory Day.

The readers will notice the transliteration of the city name (Kharkiv) into its Russian version, Kharkov, in all citations - this is because they are either original 
quotes from English-language versions of guides published in the USSR, translations of quotes from Russian, or translations of quotes from the Polish press or documents whose authors wrote about Kharkov as a Soviet city whose identity was to be expressed in Russian.

\section{"Neither the First nor the Second" - A Model Soviet Metropolis}

Though the inhabitants of Kharkiv did not much like the "Second Capital of Ukraine" moniker, most likely coined for their city by Stalin himself (Kravchenko, 2010, p. 260; Kravchenko, 2011, p. 46-47), it was eagerly used by the propaganda. The city was sometimes even ranked third in the Union "after Moscow and Leningrad" - the highest position realistically achievable. Throughout the existence of the Soviet Union, the status of Moscow was uncontested: it was the capital city, the very centre and heart of the whole USSR. It was the greatest, most modern city, closest to achieving the communist ideal; thus all other Soviet metropoles were supposed to emulate the capital city standards. While Kharkiv never surpassed the ideal of Moscow, it was always among the frontrunners. Its model status was also determined by its location in the European part of the USSR and its demographics, comprised of Russian-speaking Slavic nationalities. Its location in the southern part of the Central Russian Upland in a temperate continental climate, favourable for agriculture, means it was also devoid of any exotic associations.

Kharkiv manifested its typical nature by having a "standard" Soviet history which covered all the key components on which the identity of the USSR was founded: the October Revolution, the Great Patriotic War, and the so-called socialist urban development. The history of Kharkiv was neither as spectacular as the history of Moscow or Leningrad, nor as long as that of Tbilisi, Yerevan, or even Kiev. It was also, lastly, not as burdened with a "suspect" past as Lviv or Vilnius. It even prompted some jokes in propaganda texts: "If I were a professional tourist guide, I would never agree to work in my home town, Kharkov, in my life. It is so much easier to present, over a short period of time, a city where historical monuments have survived for ages. And Kharkov? Where could I focus the attention of curious visitors?" (Muratow, 1972, p. 8).

However, the history of Kharkiv was sufficient to call it the "city of revolutionary, military, and labour-class fame" (Gerasimenko, 1984, unnumbered p. 2; Orlenko, 1986, p. 5). For Kharkiv, the pre-modern era was relatively short and 
could be subsumed under the formula of Russian-Ukrainian unity and fraternity: "the decision of the Pereyaslav Council to unite with Russia was crucial to the development of the area, which was transformed into a strong buffer for the Russian Tsardom, protecting it from Tatars and other invaders" (Kharkivshchyna: Fotoal'bom, 1981, p. 5). Emphasis was placed on the role of Kharkiv inhabitants in fighting common enemies, such as Polish Nobles' Republic, Charles XII, or Napoleon (Kharkivshchyna: Fotoal'bom, 1981, p. 5). The $19^{\text {th }}$ century development of science and culture was presented as growth of regional, satellite variant of great Russian culture and science. It is visible in references to Vasyl' Karazin, founding father of the Kharkiv University, whom his contemporaries called the "Ukrainian Lomonosov" (Kharkivshchyna: Fotoal'bom, 1981, p. 5). Besides literary and dramatic talents associated with Kharkiv, such as Hryhorii Skovoroda, Hryhorii Kvitka-Osnovianenko, Panas Saksahansky, Mykola Sadovskii, the fact that world-famous scientists and artists such as Il'ia Repin or Nobel laureate Il'ia Mechnikov - of course seen as representatives of Russian culture and science originated there also elevated the city and its oblast (Kharkivshchyna: Fotoal'bom, 1981, p. 5).

All tourist guide-books and press materials discussed in this paper clearly emphasized the contributions of Kharkiv and its inhabitants to the October Revolution and the establishment of the Soviet power in the 1920s and 1930s: "For Ukraine, Kharkov is the cradle of Revolution. It was in Kharkov that the rule of soviets in Ukraine was declared. It was here, in the Moskalev Barracks, that the legendary commander Vitalii Primakow formed the Red Cossacks regiment, who were feared by all enemies of the Revolution" (Muratow, 1972, p. 8). Leading revolutionaries associated with the city and who in the Brezhnev era belonged to the pantheon of pan-USSR heroes were named repeatedly: Fedor Sergeev (Artem), Vladimir Antonov-Ovseenko, Grigorii Petrovskii, Grigorii (Sergo) Ordzhonikidze, Stanislav Kosior, Vlas Chubar. In the pictorial material, photographs of monuments to Lenin and the Revolution always come first and constitute 5-9\% of all imagery.

One of the key traits of Kharkiv exploited by propaganda was its relative "youthfulness". The "youthfulness" category, in general, was broadly used in the future-oriented narratives of the Soviet propaganda. Since the October Revolution established a new "beginning of time" (and thus all of history as well), "youthfulness" carried the notion of parting with the old bourgeois world and all its material and spiritual relics. After 1945, the category of youth was expanded to include also post-war reconstruction. "The architectural face of Kharkov are its streets and plazas, its residential and industrial buildings, orchards and parks build after the 
Great October" (D'iachenko, Umanskii, Oleinik1, 1967, p. 4). The pre-revolutionary urban space components, particularly those unrelated to the Revolution, were adapted into the Soviet historical discourse framework in three ways, according to Olena Kowalenko's typology: through change of function, via foundational sacrifice, or granting of status of cultural monuments that needed proper protection in the wake of the October Revolution (96-102). Though Kowalenko used examples from Moscow to illustrate this paradigm, it was clearly universal throughout the USSR. Kharkiv brings also some interesting nuances and examples. Sacral architecture was marginalized, and, should such sites appear in guide-books and albums at all, their new non-religious function was clearly marked: "Uspienskii sobor - monument of the $18^{\text {th }}-19^{\text {th }}$ century architecture. Now open as an organ and chamber music hall" (Orlenko, 1986, unnumbered p. 8).

The pictures of pre-1917 secular architecture monuments in guide-books were almost always captioned with the names of institutions they housed at the time. For instance, the caption for an impressive edifice read in bold: "The Palace of Labour", and one had to read the descriptive part carefully to learn it was originally the building of the "Rossia" insurance company in the times of Tsars. When describing history of monuments or whole city areas, the most important context was the foundational sacrifice: the 1905 and 1917 Revolutions, regardless of the sometimes longer and richer history of these places: "Monument of the Fighters of the October Revolution on Universitetskaia Gorka (University Hill). Here, (...) on 11 October 1905, armed workers and students started building barricades" (Gerasimenko, 1984, p. 1). Other examples of pre-revolutionary architecture became part of the protected cultural heritage: "The most significant buildings of the old $17^{\text {th }}-18^{\text {th }}$ century Kharkov, residential buildings and cultural monuments of the pre-revolutionary period, which show their peculiar character, are fully protected" (D'iachenko, Umanskii, Oleinik, 1967, p. 14).

The surviving pre-revolutionary material heritage was reinterpreted by assigning individual objects to the consecutive stages of social development, according to the sequence defined in the Bolshevik view of history. These stages were a modified form of Marxist historiosophy: primitive communities - feudalism - capitalism - the Soviet society. The latter encompassed both socialism and communism and was treated as the final - peak - developmental stage. It was the model view of history that spread to all Soviet museums. Organizing the exhibits according to this sequence was more important than the objects themselves. It is clearly seen in the 1967 description of the permanent exposition in the Kharkiv Historical Museum: "The Fascist occupants destroyed the Museum's precious collections and exhibits, ruined its building. After the liberation of the city, the Museum 
was quickly rebuilt, opening to the first visitors already in September 1943. The resources of the Museum were restored with great help from the museums of Moscow, Leningrad, and other Soviet cities. Currently, the Kharkov Historical Museum is one of the best in the Republic, counting over 165 thousand exhibits" (D'iachenko, Umanskii, Oleinik, 1967, p. 136).

It is clear that the important fact is that this Soviet metropolis had a historical museum and that it was large, whereas the connection between the exhibits and the region, its tradition, history, and local flavour were relegated to far lower position. The quoted guide-book does not name any of the collected exhibits or specify the age of the collections. All it stresses is that they document the class struggle and are symbols of fraternity of all nations of the USSR. The description of museum resources is so general and trite that it could easily be reused for a historical museum in any other city of the Ukrainian SSR. "The rooms of the Museum display numerous relics of material and spiritual culture, documents, tools, and household objects, which recreate the history of the Ukrainian nation and its inextricable ties to the history of the Russian nation and other fraternal nations of the USSR" (D'iachenko, Umanskii, Oleinik, 1967, p. 138).

A key part of a "full" Soviet history was heroic participation in the struggle against the German occupant in the years 1941-1945, a major weakness in Kharkiv's model biography. Although the propaganda was silent about the Red Army's failures in the Kharkiv region and its having to liberate the regional capital twice (on 16 February and again 23 August 1943), Kharkiv was never named a Hero City (Kravchenko 2010, p. 260). The fact that Mikhail Koshkin designed the most famous tank of World War II, the T-34, in the design offices of the Kharkiv Locomotive Factory, and that the factory manufactured it in the years 1940-1941, was almost entirely ignored in the studied material. Just a single, laconic reference to the T-34 tank as the city's contribution to the all-Union production of armaments appears in the photo album Kharkivshchyna (p.11). That the T-34 never became the leitmotiv of the Soviet war discourse about Kharkiv is most likely because in 1945 manufacturing of the tank was inherited by the successor of the Kharkiv Locomotive Factory: the Kharkiv Diesel Factory No. 75 (renamed the Malyshev Plant in 1957). What is more, after 1945 there were only two design bureaus which developed new types of tanks in the whole of the USSR: in Nizhny Tagil and in Kharkiv. The Malyshev Plant is also never mentioned in the "Soviets' State", in spite of being one of the largest employers in the city of Kharkiv. Of all analyzed tourist guides, the factory is referenced in two (Andreeva, Oleinik, 1982, p. 44-46; Gerasimienko, 1984, p. 16), but only as a plant manufacturing combustion engines for locomotives. Why the legend of the T-34 tank, which 
could have been seamlessly integrated into the cult of the Great Patriotic War revived in Brezhnev's times, had been thus ignored? Simply put, to keep the military technological know-how a secret after the war.

\section{Industrial Giant in the Middle of an Agricultural Region}

A model soviet metropolis had to be an industrial city. Admittedly, the dominance of industry over agriculture, city over country, and worker over peasant was not as destructive under Brezhnev as it was when the Soviet rule was first being established. Moreover, the conservative wing of the CPSU came up with the idea of modernizing the Non-Black Earth Region in the central part of the Russian FSSR, which implicitly improved the recognition of the Russian ethnos and the countryside itself (Vanderheide, 1980, p. 218-228). Rural themes were also present in domestic Russian literature, taking the form of the Village Prose (derevenskaia proza) movement. Its representatives turned to traditional values, reality of country life and rural landscape (Dunlop, p. 80-87). Nonetheless, favouring the city over the country, and consequently industry over agriculture, was the clou of the Soviet economic policy until the end of the USSR. Within industry, its heavy branches attracted the most attention. Perception of heavy industry as the priority was not affected even by reorientation of manufacturing priorities initiated under Khrushchev, which prepared the ground for the Brezhnev era mass consumption.

Kharkiv fit these assumptions perfectly. In the real socialism period, it was one of the largest machine-building centers in the whole USSR. It was the location of the Kharkiv Tractor Plant, the Kirov Turbine Plant, the Lenin Electrotyazhmash, the Kharkiv Electric Mechanical Plant, the Machine-Tool Plant named after S.V. Kosior, the Serp i Molot Motor-Building Plant, and many others. These plants manufactured tractors, turbines, generators, electrical equipment for locomotives, electrical installations, various types of engines, machine tools, and bearings. As mentioned above, the Malyshev Plant disappeared from the foreground of propaganda messages after 1945 . The only - and not obvious by far - connection between the city and armaments production in the studied sources could be found in the essays by Yurii Gerasimenko, who mentioned famous people educated there: one of them was allegedly Pavel Rybalko, later a Soviet military leader and marshal of the armored troops (Gerasimenko, 1984, p. 16).

The industrial face of Kharkiv was the most prominent feature of the propaganda descriptions. It always came first, followed by science and culture. The 
phrase "industrial, scientific, and cultural centre" could feature as "industrial and cultural" or "industrial and scientific", but "industrial" was always the first adjective. The following elements were characteristics of Kharkiv's industry descriptions: The machine industry was promoted the most; other branches also present in Kharkiv, such as the textile or food industry, remained in the background. The pictures of production facilities showed both men and women. Photographic material attested to gender equality, officially adopted in the USSR; e.g., women were shown not only as secretaries or waitresses in factory canteens but also as engineers, designers, and workers performing "typically" masculine tasks. Furthermore, the industry was of tremendous size. Sescriptions of individual plants abounded in nouns and adjectives indicative of grandeur, such as "impressive", "great", "giant", "colossus". "The Kharkov Tractor Plant is amazing. Mostly due to its size. It is a small town, complete with streets and alleys running along departments furnished with thousands of machines operated by tens of thousands of workers" (Fil, 1979, p.16).

The size of production facilities was typical for the "developed socialism" era. Most importantly, it was stressed, unlike in the times of Tsars, it was achieved through joining of national engineering thought and labour: "There are no more dwarf factories, nor Gelferichs, von Ditmars, nor Pilstems" (Kurasow, 1966, p. 5). Quality of the Kharkiv industry was underpinned by collaboration between various research institutes, laboratories, and workplaces. Their products were exported to about 60 countries worldwide, including the West, where - which was particularly stressed - they were highly acclaimed: "The products of the Kharkov [Bearing] Plant are eagerly bought by 25 countries. Talks with representatives of Italian companies took place recently. It is notable that even Sweden - known favourite in rolling bearings - also buys products from Kharkov" (Charkowscy jubilerzy, 1966, p. 12). "The Soviet hall [at the Poznań International Fair in 1967] was one of the largest on the fairground. (...) The Soviet exposition had many products from Kharkov, namely a model of the new TU-134 plane, a lathe of high performance and precision, the already world-famous F-D cameras made in Kharkov, named so in honour of Felix Dzerzhinsky, and other exhibits. We are convinced that the Poznań inhabitants who visited the Soviet hall showed interest in the new washing machine "Kharkovchanka», beautiful fur products from Kharkov, and a new type of bike bearing the arms of Kharkov" (Złodjuszko, 1967, p. 3).

The industry of Kharkiv - indubitably of both pan-Union and export importance - was demonstrably perfectly correlated with the agricultural nature of its surrounding region: "The local industry satisfies the technological hunger of the Ukrainian black earth, with tractors leaving the assembly lines one by one. The 
Black Sea is also in sight, as Kharkov manufactures powerful ship turbines" (Gryfin, 1966, p. 4). The link between industry and highly developed agriculture was noted by the $1^{\text {st }}$ Secretary of the Regional Committee of PZPR in Poznań, Wincenty Kraśko, in the letter of intent for cooperation sent to the Oblast Committee of the Commmunist Party of Ukraine already in 1957: "Our cities - Kharkov and Poznań - and our provinces face a number of similar economic, cultural, and scientific problems. We know that Kharkov is one of the largest industrial centres of Ukraine and the whole State of Soviets. The agriculture of the Kharkov Oblast is famous for its high efficiency and degree of mechanization. Our city and province play a similar role in the Polish economy" (APP, 53/2183/0/4/328, p. 200).

Partnership between Kharkiv and Poznań was a very frequent topic of articles published in the Soviets' State and The Poznan Gazette. All the common activities described there, from senior-level party visits, to meetings of industrial, scientific, and cultural directors, artists, journalists, industry professionals, to exchanges between members of workers' collectives, students, and youth "took place in a cordial atmosphere" and "resulted in fruitful exchange of experiences". More often these were one-sided, where Kharkiv, embodiment of the USSR in its relationship with the People's Republic of Poland, took the role of an instructor bringing new technologies to its Poznań partner: "many come here to gain know-how. For example, a delegation from Poland came last year. Our oblast is friendly with the Poznań Voivodeship, and our factory has links with the H. Cegielski Works. Its Polish smiths experienced difficulties when pressing shafts - the elements often seized up in the press tool. We do not keep our "secrets" hidden, so we told our Polish friends how they should modify the technology. It was implemented and the Polish smiths have gained much in speed of their work. Now we are receiving many letters from Poland showing gratitude" (Batałow, 1966, p. 12). Such was the tone of some of the studied archival documents dating from the late 1950s; instructions for delegations leaving for Kharkiv included comments such as: "get acquainted with the latest technological advances", "get acquainted with the newest literature", "bring samplings" (APP, 53/1228/0/29/2061, p. 1-3).

Balanced development of Kharkiv was very important in the propaganda message - social infrastructure of the city was to develop in parallel to quantitative and qualitative increase in production. A significant proportion of content, including illustrative material both in the press and the guide-books, was focused on newly-built housing complexes with various amenities for their inhabitants. "Districts should be self-sufficient urban micro-organisms, with their own centres, institutions, and enterprises, able to fulfill all the livelihood and cultural needs of their inhabitants. These districts should even have their own freeways to connect 
with one another and avoid blocking access to the city centre" (Sizonow, 1966, p. 8). "Huge government spending goes to construction of housing and public services buildings. Just this year, about 400 thousand square metres of floor space will be completed. The plans include construction of many schools, healthcare facilities, kindergartens, nurseries, cinemas, and a concert hall" (Laboga, 1966, p. 5). The construction of prefab concrete housing complexes - the flagship program of the Soviet domestic policy in the Brezhnev era (still insufficient to meet the needs) - was perhaps the most exploited propaganda theme. The housing construction rate was to be the indicator of living standards and the city's prospects. Impressive numbers were used, often varying between sources and given without offering any context, e.g.: "[in Kharkov,] more than 80 families move into new apartments every day. The total floor space has now exceeded 21 million square metres" (Andreeva, Oleinik, 1982, p. 2).

The urban services and entertainment space for Kharkiv inhabitants was to consist of numerous cultural centres, libraries, theatres, a planetarium - mandatory after the Thaw, one of the oldest zoos in the USSR, and the bellwether of the Soviet entertainment canon - a circus (Andreeva, Oleinik, 1982, p. 2). Kharkiv was to foster sporting activities of its inhabitants, offering extensive sports infrastructure: 16 stadiums, 98 playing fields, 350 gyms, 15 swimming pools, plus tennis courts and many more (Orlenko, 1986, p. 8). Despite its definitely industrial nature, it was meant to be simply a pleasant place to live, with a lot of greenery incorporated in the city space, and the Gorky Central Park of Culture and Leisure as the principal place of outdoor family recreation. Finally, the inhabitants were to be served by modern public transport (tramways, trolleybuses, buses, suburban railway) which, at the close of the Brezhnev era, carried over 2 million passengers daily (Andreeva, Oleinik, 1972, p. 6). Having a subway system was indicative of modernity and prestige as well. Kharkiv subway started operating in 1975 as the sixth city in the USSR (Gerasimenko, 1984, p. 26) and shared the experiences from its construction with Poland (Neswytenko, 1975, p. 11).

\section{Students of all Countries, Unite}

The role of Kharkiv as an academic and scientific centre was almost always listed second after its industrial function, occasionally third after its cultural functions. Pictures demonstrating the city's scientific potential amounted to $8-15 \%$ of all illustrative material in the studied guide-books. The texts emphasized that the science complex of Kharkiv was a significant portion of the entire Ukrainian SSR 
academic sector. At the close of the era, one seventh of all research workers and one fifth of scientific institutions of Soviet Ukraine were located in Kharkiv (Andreeva, Oleinik, 1972, p. 3; Orlenko, 1986, p. 164; Gerasimenko, 1984, p. 32). The number of higher education institutions was presented without always caring for precision. For instance, in a 1966 issue of the Soviets'State, in one article the number of higher education schools in Kharkiv was given as 21 (Laboga, 1966), while another article on the very same page cited 23 such schools (Kurasow, 1966). In general, the numbers given were always above 20 . The (sometimes approximate) number of research institutes based in Kharkiv was also recalled often, oscillating between 40 and 60 .

Engineering and exact sciences education were at the forefront of the propagandist message. The direct influence of scientific achievements originating in Kharkiv on technological progress and economic development of the USSR, including in such key sectors as space exploration and nuclear power, was stressed. The primacy of Kharkiv in the world was noted (which by itself meant primacy of the USSR). "They [scientific workers of Kharkov] carry on much important work in the field of exploration of outer space, nuclear physics, mathematics, machine-building, biology, medicine" (D'iachenko, Umanskii, Oleinik, 1967, p. 77). Just like the propaganda descriptions of industry in Kharkiv left out the Malyshev Plant, so did the accounts of the science and research sector skip the institutions carrying out research and development for the military, e.g., the Scientific Production Association "Elektropribor", also known as the Experimental Design Bureau 692 (Postal box 67) producing control systems for ballistic missiles, now operating openly as Hartron. Usually medicine was rated right behind exact sciences in importance, whereas social sciences and the humanities were left in the background.

Kharkiv was also characterized as a "student city". The numbers of students studying in Kharkiv were cited in many sources: 160,000 (Gryfin, 1966), 93,000 (D'iachenko, Umanskii, Oleinik, 1967, p. 76), 132,000 (Gerasimenko, 1984, p. 32), 132,000 (Orlenko, 1986, p. 8). One often named feature of Kharkiv was a large number of foreign students and interns: "It is here that young men and women from many world countries come for education, here specialists from various companies and institutions from Europe, Asia, America, and Africa gain experience. Their voices resound in factories and construction sites, in science and research institutes of the city and the oblast" (Kharkivshchyna: Fotoal'bom, 1981, p. 16).

It was, however, difficult to find more detailed information regarding the life of students, such as about their accommodation, leisure activities etc. in the propaganda narratives. Accounts about students, including foreign students, were 
very vague, limited to platitudes and cursory descriptions of gaining skills and knowledge: "During the so-called working semester, Polish students worked at the Scientific-Research Institute of Plant Industry. Hand in hand with their Soviet colleagues, Poznań students helped researchers perform various experiments" (Neswytenko, 1974, p. 26).

As already mentioned, the illustrative material books focused on science and education in the Kharkiv guides was extensive. The pictures, however, mainly showed the buildings of higher education schools and institutes, lecture halls and laboratories. Students were always shown - if at all - in lecture halls or reading handbooks. Out of 70 pictures, dormitories could be found only in two. Pictures of students outside of classes could only be seen occasionally. A photograph called "before examinations", showing a female and a male student sitting back-to-back on a lawn reading handbooks was the peak of romanticism (Gerasimenko, 1984, unnumbered p. 24). The propaganda discourse did not touch upon the topic of mutual interactions between domestic and foreign students at all. As Volodymyr Kravchenko (2010, p. 268) duly noted, it is one of so-far unexplored themes in the contemporary history of Kharkiv.

Writing (albeit quite vaguely) about Kharkiv as an internationalist educational centre logically means there was also a reverse message being communicated: one about "international(ist) Kharkiv for the world". One issue of The Poznań Gazette included material about a physician from Kharkiv working in Algeria: "Aleksander Karczewski is a representative of Kharkov medical circles working far from his home town. Dozens of physicians have been working in the distant Cambodia, Algiers, Kenya, and other countries in Asia and Africa, providing valuable aid to indigenous populations in fighting diseases and building modern healthcare facilities" (List z Algieru, 1966, [Letter from Algiers], p. 8).

\section{Conclusion}

Without a doubt, the image of Kharkiv outlined in propaganda materials intended for foreign recipients, including the citizens of the Polish People's Republic, largely met the requirements of the model Soviet metropolis image. Kharkiv was characterized as a high-ranking, important industrial, scientific, and cultural centre, one that surpassed in significance all other non-capital cities of the USSR republics (with the exception of Leningrad). The propaganda intended to prove to foreign recipients what a "normal" city could achieve in the USSR, provided that its inhabitants were actively and industriously fulfilling the tasks assigned by the Party. 
Modern research confirms that the image of Kharkiv, which was formed in Soviet times, had a lasting impact on the identity of the city's inhabitants (Musiiezdov, 2009, p. 16-21). Kharkiv was meant to be a role model for Poznań and Poland: any discussion of cooperation largely followed the pattern of "come to Kharkiv and learn from us". Occasionally, examples of skills and knowledge transfer in the opposite direction were given as well.

In a thus constructed image, the Ukrainian identity of the city was of marginal importance. Whereas one could read in the guide-books about the monuments of Taras Shevchenko and Ukrainian-speaking scientific and cultural institutions, the Ukraininess of Kharkiv in press texts addressed to Polish readers was purely geographical. In general, the image of Kharkiv studied here contains little specificity or the so-called local flavour. Texts intended for tourists and potential tourists make no mention of local cuisine, traditional local products, or souvenirs. It can be linked to one more noticeable phenomenon: the industrial, scientific, and cultural sectors of Kharkiv were present in the analyzed material, while the whole sphere of commerce and services was mostly absent.

The version of Kharkiv history shown in the discussed material followed the formula of "complete" Soviet history with its three key components: the Victorious 1917 Revolution, the Great Patriotic War, and socialist urban development. At the same time, this history was smoothed over and missing any controversial topics: when prominent Communists associated with Kharkiv were listed (Vlas Chubar, Pavlo Postyshev, Stanislav Kosior), there was no mention that they fell victim of the Stalinist terror of 1937-1939 or that they were only rehabilitated in 1956 or later. The topic of Kharkiv serving as the capital city of the Ukrainian SSR until 1934 was marginalized, doing away with the distinctiveness of Kharkiv in the 1920s, both identity-wise (as the centre of Ukrainization) and aesthetically (as the centre of Modernism and Constructivism). The Derzhprom building, while broadly described and frequently presented in pictures, was listed simply as one of the many achievements of Soviet architecture, not as a monument of a time of particular elation and success in the city's past.

In its presentation of Kharkiv, propaganda was generally based on rational arguments: it adduced many figures and constantly referred to the scientific and technological progress. The Soviet Kharkiv was a city of youth - this was message reinforced by slogans and pictures, showing hardly any older people - yet it was a highly rational youth, believing in science, technology, and a better future. 


\section{References:}

Andreeva, G., Oleinik, V. (1982). Znakom'tes': Khar'kov: Putevoditel'/Get Familiar with Kharkov: Guide/Faites la connaissance de Kharkov: Guide. Kharkov: Prapor.

APP - Archiwum Państwowe w Poznaniu. [State Archive in Poznań].

Batałow, W. (1966). Charkowska Fabryka Traktorów. Kraj Rad, 28(416), 10-12.

Bremzen, A. von. (2016). Szarlotka Lenina i inne sekrety kuchni radzieckiej. Kraków: Wydawnictwo Uniwersytetu Jagiellońskiego.

Charkowscy jubilerzy. (1966). Kraj Rad, 50(438), 12.

Chernyshova, N. (2015). Soviet Consumer Culture in the Brezhnev Era. Abingdon: Routledge.

D’iachenko, N. (1965). Ulitsy i ploshchadi Kharkova: Iz istorii goroda. Kharkov: Prapor.

D'iachenko, N., Umanskii, M., Oleinik, V. (1967). Khar'kov: Putevoditel'/Kharkov: Guide-book. Kharkov: Prapor.

Dunlop, J.B. (1980). Ruralist Prose Writers in the Russian Ethnic Movement. In: E. Allworth (ed.). Ethnic Russia in the USSR: The Dilemma of Dominance (pp. 80-87). New York: Pergamon Press.

Ellul, J. (2006). The Characteristics of Propaganda. In: G.S. Jowett, V.O'Donell (ed.). Readings in Propaganda and Persuasion: New and Classic Essays (pp. 1-50). Thousand Oaks, London, New Dehli: Sage Publications.

Fil, A. (1979). Historia z traktorem. Kraj Rad, 39(1104), 16-17.

Gerasimenko, I. (1984). Vstrechi s Khark'ovom/Meetings with Kharkov/Begegnungen mit Charkow. Kharkov: Prapor.

Głowiński, M. (1991). Nowomowa po polsku. Warszawa: PEN.

Gryfin, M. (1966.03.12). Charków miasto entuzjastów. Gazeta Poznańska, 60, 4.

Kaganskii, V. (2004). Sovetskoe prostranstvo - nashe nasledstvo. Retrieved from: old.russ. ru/culture/20040820_kag.html.

Kharkivshchyna: Fotoal'bom (collective edition). (1981). Kharkiv: Mystetstvo.

Kowalenko, O. (2014). Moskwa olimpijska: Studium semiotyczne. Kraków: Libron.

Kurasow, W. (1966). Przypomnienie paru zdań. Kraj Rad, 28(416), 5.

Kravchenko, V. (2011). Ukraina, Imperiia, Rosiia: Vybrani statti z modernoi istorii ta istoriohrafii. Kyiv: Krytyka.

Kravchenko, V. (2010). Khar'kov/Kharkiv: Stolytsa Pohranycha. Vil'nius: EGU.

Kul'chyc'kii, S. (2013). Chervonii vyklyk: Istoriia komunizmu v Ukraini vid ioho narodzhennia do zahybeli. Knyha 3, Kyiv: Tempora.

Laboga, I. (1966). Kwitnące miasto. Kraj Rad, 28(416), 5.

List z Algieru. (1966.12.24-25-26.). Gazeta Poznańska, 305, 8.

Martyn, T. [= Martin, T.]. (2013). Imperiia natsional'noho vyrivniuvannia: Natsii ta natsionalizm u Radians'komu Soiuzi (1923-1939 roky). Trans. by Serhii Vakulenko. Kyiv: Krytyka.

Muratow, I. (1972). Nowy herb. Kraj Rad, 24(672), 8-11.

Musiiezdov, O. (2009). Kharkivs'ka identychnist': uiavlennia pro misto ta ioho istoriiu jak chynnyky identyfikacii”, ece-urban. Pobrane z: http://www.lvivcenter.org/uk/publications/ece-urban. 
Neswytenko, M. (1972). Na południku charkowskim. Kraj Rad, 8(708), 23.

Neswytenko, M. (1974). Mówią Charkowianie. Kraj Rad, 42(846), 26.

Neswytenko, M. (1975). Charkowscy budowniczowie metra dzielą się doświadczeniem. Kraj Rad, 4(860), 10-11.

Orlenko, I. (1986). Turistu o Kharkove: Putevoditel'/Kharkov: A tourist's guidebook. Kharkiv: Prapor.

Sizonow, L. (1966.12.24-25-26). Spojrzenie w przyszłość. Gazeta Poznańska, 305, 8.

Slezkine, Y. (1994). The USSR as a Communal Apartment, or How a Socialist State Promoted Ethnic Particularism. Slavic Review, 53(2), 414-452.

Teslenko, V. (ed.). Kharkiv/Khar'kov/Kharkov. [no publication date]. Moskva: Progress.

Thom, F. (1990). Drewniany jezzy. Trans. by Izabela Bielicka. Warszawa: CDN.

Vanderheide, D. (1980). Ethnic Significance of the Non-Black Earth Renovation Project. In: E. Allworth (ed.). Ethnic Russia in the USSR: The Dilemma of Dominance (pp. 218-228). New York: Pergamon Press.

Złodjuszko, O. (1967.02.01). Przynajmniej raz trzeba zobaczyć Poznań. Gazeta Poznańska, 155, 3. 